\title{
The Memory and Poetics of Maria Bonomi - A Social Discourse
}

\author{
Alecsandra Matias de Oliveira* \\ Doctor in Visual Arts, School of Communication and Arts, Universidade de São Paulo - ECA USP, Specialist in Universit, \\ Cooperation and Extension, Museu de Arte Contemporânea - MAC USP \\ *Corresponding author: alemaoli@usp.br
}

Received August 03, 2013; Revised October 22, 2013; Accepted February 12, 2014

\begin{abstract}
This study deals with the relations between memory and art, especially the contemporary art seen in architectural monuments in the city of São Paulo. With this aim, the art history and its aesthetic developments are used as a tool for the research, focusing on the poetics of memories by Maria Bonomi one of the most important artists of the national artistic circuit.
\end{abstract}

Keywords: Brazilian art, contemporary art, history, Maria Bonomi, São Paulo

Cite This Article: Alecsandra Matias de Oliveira, "The Memory and Poetics of Maria Bonomi - A Social Discourse.” American Journal of Educational Research, vol. 2, no. 2 (2014): 78-83. doi: 10.12691/education-2-2-3.

\section{Introduction}

As an artist, I interpret, I make the report of some striking experience, the visual description of day-to-day feelings. I "truly" register each encounter that moves me [1].

Maria Bonomi's career is intimately linked with printmaking. From her beginning at Lívio Abramo’s studio in the 1950s, to her professional maturation in the 1960s, the technique of woodcut has allowed the artist to participate in and receive awards from several editions of the Bienal de São Paulo as well as other national and international exhibitions. Maria Bonomi's aesthetic past demonstrates, in a general sense, that the thematization of social questions is not opposed to formal rigor, that constructivism can be lyrical, that printmaking can share concerns with public art - the central concern of Maria Bonomi's artistic production is directed toward the ideals of accessibility and aesthetic awareness. How is Maria Bonomi's poetics constructed based on her memories? What are her basic and instrumental presuppositions? And, mainly, how does the artist develop a production related to her socially engaged posture?

The artist's attribution of a social dimension to printmaking, which gradually evolved into public art, had its origin in large-format works. An outstanding work along this path was Balada do Terror (Três estágios) [Ballad of Terror (Three stages)], 1970, a woodcut printed in a run of 30 copies which expresses Maria Bonomi's political engagement, which she perhaps inherited from Lívio Abramo. At the height of the period of the most intense repression by the Brazilian military dictatorship (1964-1984), the artwork was transformed into an instrument of combat and denunciation. Maria resorted to a printmaking of argumentation without the need for pamphleteering. According to Paulo Herkenhoff, "this politicization of the abstract is the greatest dimension of sociability in Maria Bonomi's oeuvre” [2]. The artist breaks the paradigm of traditional printmaking done in small formats, impressing the mark of vivid memories onto the reading of the work.

\section{The Works}

In Balada do Terror, besides the application of the technique of woodcut to large-format works on paper, the artist applies, constantly in abstract language, the procedures of seriation and repetition. In this work, the artist unveils a new manner of using the printing matrix, transforming it into a module that is repeated, fractionated and moved in various directions during the process of printing. In an interview, Bonomi explains how she arrived at this procedure. Curiously, this arose from an experiment with sound; upon watching a sound technician cutting and editing magnetic tapes, the artist thought: "If a sound can be elaborated, transformed, 're-transposed' in this way, why not a matrix? And since it could be moved, I decided to alter the dynamics of those lines, the vibration of those backgrounds, in order to attain a greater eloquence of the language" [3].

In Mar dos Apoios [Sea of Supports] (1972) and Como se Fossem Palavras [As If They Were Words] (1975) prints inspired in Amazonia and in China - the artist visualizes the most remote regions of the Amazon Forest and the South of Bahia, making a report by way of graphic annotations. In China, the nation of age-old memory, she entered the intimacy of the ancient Oriental woodcuts, which constitute the roots of contemporary woodcut. The series Como se Fossem Palavras form a visual sequence. The woodcuts arranged side-by-side constitute phrases "as though they were words" - a visual code created by Maria 
Bonomi. In them we can perceive the artist's desire to express her life experiences.

[...] My works were executed over graphic annotations [...]. In the Amazon Forest and in southern Bahia there are very fertile images, since in these regions I had the opportunity to gain intimacy and firsthand experience with the landscapes, animals, plant life and rivers that offer great artistic values [...] my trip to China was directed more to searching for the origin of woodcut $[. .$. [4].

In abstract expression and in monumental format, her prints involve narrative and biographical aspects. Open to experimentations, the artist imprints personal marks on her artistic production, allying technical innovations, intimate feelings and politicosocial manifestation. The prints are communication vehicles aimed at social dissemination. The dissemination of art is a crucial point in Maria Bonomi's poetics. A proof of this is her eager participation in actions such as the collective studio with Lívio Abramo as well as the collective initiatives that the artist has organized throughout her career.

Módulos Salombras [Salombra Modules] (1972) and Epigramas [Epigrams] (1984), objects motivated by Clarice Lispector, are printing matrices elevated to a new artistic condition: based on clay, Bonomi brings about the emergence of reliefs and textures, lines, and grooves that were later cast in metal - bronze, brass and aluminum. The works represent a variety of forms whose main point of interest is the rhythm of the groove. The artist multiplies and reproduces the only non-multipliable part of the print, the matrix. Within this set she configures the radicalization of the procedure of seriation and repetition to the point where the work of printmaking is transformed into a sculpture, altering the dimensionality of the piece.

The supports of woodcut were gradually transformed. Based on the large formats, the language acquired tridimensionality with the reproduction of the matrices and, finally, in 1976 - with the execution of the Tríptico da Igreja Mãe do Salvador [Triptych of the Mãe do Salvador Church] - entered into the irreversible terrain of monumentality. This was the beginning of her production of murals. In her visual path, Bonomi has alternated murals with printmaking, and has even combined them. However, she always uses "living memories.” From 1987 to 1996, the artist created prints whose graphic syntheses exploded in passion and vitality; Sappho I, from 1987, and Apoteose [Apotheosis], from 1993, are examples of this. In them, the striking color reveals the interplay of transparence and disclosure. She made O Pente, Tempo... [The Comb, Time...], a woodcut from 1993, in which she relativizes the banality of day-to-day life, attributing monumentality to everyday events. In a similar way, based on the interpretation of experiences, the artist created her Medusas [Jellyfish], woodcuts begun in 1993 and presented in 1996. In these, Maria Bonomi registers the sensations of an attack by jellyfish during a dive. In the series Tropicália, 1994, based on an incursion into fractal art, she created an image originated in the manipulation of matrices that compose a form that is made, unmade and remade.

Her tridimensional production included the mobile sculpture Páginas [Pages] (1997), destined for the garden of the Arquivo do Estado de São Paulo [São Paulo State Archive]. In this work, Bonomi grooves the surface of the model in clay as though she were writing with her tools the relation of writing in Maria Bonomi's poetics is significant. It is enough to remember the graphic specificity of her prints and, especially, the series Como se fossem palavras which refers to the universe of Chinese writing. In Páginas, the writing is cast in aluminum for posterity. The inscription is eternalized, according to the artist's wish, in public memory. The Archive, the place of memory, has sculpture as a guardian of its functions of imparting life and reminiscence. The wind and the daily movements of urban life take charge of altering the writing - because the sculpture has movement and can be reconfigured.

\section{Creative Process}

In terms of her creative process, it can be noted that Maria Bonomi begins with an annotation or a record, that is, an actual life experience composes the visual memory, which will be elaborated and transposed to the material. The woodcut is the path of creation - even when the support is not wood or paper - the graphic meaning of her works prevails no matter what the support. The grooves and molds become present not only in the bidimensional but also in the tridimensional realm. The monumentality is put into the large-format prints and also in the narrative aspect. The theme becomes a crucial point - it is the mark of time and of the memorable facts. Here, the memorable does not concern only "great feats"; it can also involve banal happenings from everyday life.

The narrative aspect is aimed at sharing memories, disseminating the reflection and, especially, raising awareness for life. The theme arises from the artist's wish. It is transmitted by the work to the spectators who resort to their own, individual memories to resignify it. In this sense, Maria Bonomi, even in abstract expression, approaches art as a form of knowledge, because in her conception, art transmits the message. This point of view has been manifested in various interviews given by the artist:

[...] the work of art has its origin in the references of human knowledge. I therefore consider that in every sense the work of art is a form of knowledge [...] In my sector, it is the visual knowledge [...] at the moment of my expression, I am expressing the knowledge that I have of the others, who surround me, the world in which I live. In this sense, art is transformation [5].

In her search for a transformative art, Maria Bonomi began her intervention in public space in the late 1970s the same period when public art enjoyed ample stimulus and financing, especially from the NEA and GSA in the United States, and the Arts Council in Great Britain. In the latter half of the 1980s, there was a strong push in cultural politics toward this type of art, particularly in European cities such as Berlin and Düsseldorf (both in Germany). Some cities, such as New York, systematically encourage the acquisition and exhibition of artworks in recently constructed public and private buildings.

For Bonomi, "public art is different in terms of its genesis" [6]. It concerns the renewal of aesthetic sensibility. And this necessarily implies its shaping, to a decisive degree, by the circumstances and conditions of each specific place [7]. Most of the artists who work in the 
area of public art adopt an engaged posture in their works, seeking to alter the surrounding cityscape and, in some cases, recovering degraded spaces, encouraging the debate on social problems and issues. Maria Bonomi assembles these ideals, expressing her desire for the valorization of the urban space; however, in her view the work should develop the population's artistic perception while also being adapted to its surroundings to assure its social insertion in the urban scene:

Nowadays what is being questioned is not art, but the space that is reserved for it. We have destroyed the natural landscape and have not substituted anything in its place. In the streets, there is only functional aggressiveness [...]. When one designs a public artwork, one should consider not only its function, but also its visual aspect in the collective space. These buildings contain incredible luxury, how can it be that the street is such a terror? [8]

\section{The Public Art}

Maria Bonomi sees public art as a response to modern architecture. As a printmaker, her aim is to free woodcut from its genealogy in terms of format and treatment, lending it an urban dimension. The intimist exhibition of the artwork does not satisfy Bonomi's aesthetic project.

This project strongly involves the desire to leave the book and go to the wall, to leave individual contemplation, going to a proposal for permanent and collective participation. In the mural, the artist creates compositions on huge areas of wood that are later covered by reinforced concrete. The foundation of this work is in printmaking, that is, in the procedures of seriation and repetition, though also accompanied by the procedures of sculpture. Reinforced concrete, when finished, becomes a single piece, in opposition to the production in series offered by printmaking. This different nature constitutes the mural which, through its high and low reliefs, constructs the landscape. It thus reassumes the ideas of Milton Santos on the landscape. In this case, the mural aims to be a place of memories, in which society attributes aesthetic functions and content. It is the human factor that constructs, attributes meaning and transforms the space into landscape.

The experiment of the Espaçovivo [Livespace] project, carried out in May 1973, in a building under construction on Rua Caiowaá 2251, Sumaré District, São Paulo, conceived by Maria Bonomi, begun by Nicolas Vlavianos and financed by Construhab, converted the building's lobby into a transitory art studio, where the artist executed a work-in-process open to the public. The experience of the art studio was born in a previous action, at the Museu de Arte Moderna do Rio de Janeiro, 1971, when Maria Bonomi executed her prints under the watchful eye of the public. For two months Vlavianos worked surrounded by construction workers and apartment buyers. Students were invited to learn about the experiment, and the residents of that district, neighbors of the construction project, joined with the spectators of the work-in-process.

During the course of the work the artist altered many elements of the art project: he changed the color of the walls and took down the panel several times. All of the materials used were common construction materials: "I used common latex paint, steel, iron. A bricklayer fastened it, painters from the building itself painted it, two laborers worked in the setup. I planned everything, chose the colors, mixed them" [9]. The Espaçovivo project also foresaw the participation of Fernando Lemos, Toyota, Paulo Becker, Calabrone, Ely Bueno, Amélia Toledo, Norberto Nicola, Jacques Douchez, Ianelli, Anésia Pacheco, Maria Helena Chartuni, Evandro Jardim and Maria Bonomi herself. However, the first action with Vlavianos ended when the financing was discontinued.

For Maria Bonomi, Espaçovivo and the experience in the studio, set up in MAM RJ, in 1971, allowed for an approximation and interaction with the public. This exercise was similar to the beginning of a project of public art, in which it is necessary to interact with the urban environment and with the population of the locality where the work will be installed. In Maria Bonomi's praxis, it is fundamentally important that each region be studied, examining the frequency of people (who they are; their needs) and recovering histories and memories able to sensitize that audience.

In 1999, Maria Bonomi defended the thesis "Arte Pública - Sistema Expressivo/Anterioridade” [Public Art - An Expressive System/Anteriority], at the School of Communications and Arts of the Universidade de São Paulo. In this work, she discusses her experience with public art and, especially, establishes three modalities of public art developed up to then:

- Inserted - an artwork created throughout the civil construction process, with a structural aesthetic function within the original design. The artistic design is idealized before the conclusion of the building's construction;

The artist cites as an example of this first trend, among other works, the panels Paisagem [Landscape] and Memoria [Memory], 1979, installed in the Maksoud Plaza Hotel.

- Parallel - a work created to be applied to a preexisting surface, as an element for improving the available space. It is not always functional;

As examples of this second type, Maria Bonomi cites Ascensão [Ascension], 1976, a panel in the Mãe do Salvador Church, and the panel Construção de São Paulo [Construction of São Paulo], 1998, installed in the Jardim São Paulo Subway Station.

- Posterior - a work which, by its scale, spatial and circulatory localization, acts isolatedly.

As examples of this third type, the artist cites the mural Futura Memória [Future Memory], 1989, at the Memorial da América Latina, and the panels Imigração [Immigration] and Substituição [Substitution], 1998, installed in the Palácio dos Bandeirantes - the headquarters of the São Paulo State Government.

Based on the ideas registered in her thesis on public art, Maria Bonomi developed her aesthetic project, considering the technical and artistic aspects related to each production, but, above all, the artist points out that each new artwork has its own history.

Public art, in the practice organized by Maria Bonomi, is aimed at recovering the aesthetic gaze for the urban environment, recovering degraded, inactive spaces and transforming them into "places of memory." That is, places able to convey meaning, reestablish erased or devalued memories, stimulate reflection, and raise awareness. The artist exemplifies her concept of public art as: 
Public art is placed into opposition with transitoriness to become a reference. It cannot be frivolous. It comes to alleviate the fleeting advertising space and it is a clear repulsion of certain "visual circumstances." It proposes to rearrange reality, to give rise to confrontations. To reestablish the relations of the city with the community [10].

In this sense, it is worth revisiting the discussion on the question of transitoriness of the places that currently represent the city and the community of São Paulo. Amidst the phenomenon of globalization and deterritorialization, public art, as Maria Bonomi states, is presented as a reference - something that serves to organize the urban chaos. By way of affective aspects, public art recovers the feeling of being "at home” because its first attribute should be the identification of that artwork with the memories and histories of that population.

The monuments, a form of public art scattered throughout the city, are taken as the last dwelling places of a population's identifying features and feelings of affectivity. In the urban setting, these monuments receive the memories of different eras and manage to convey most of them to their spectators. In the specific case of Maria Bonomi, public art is seen, moreover, as a vehicle for aesthetic propagation, for ordering the landscape and, above all, for democratic enjoyment. The artist dedicated herself to a reflection on urban issues (including political and social aspects in this context) that involve São Paulo, and went on to unfold her activity to other national and international locations as well.

Maria Bonomi's first initiative in regard to public art and her large panels took place in the construction of Ascensão, a triptych at the Mãe do Salvador (Cruz Torta) Church, 1976. A significant challenge: confront a liturgical space without resorting to conventionalisms. Bonomi realized a "kind of visual history," in which her objective lies in the symbolism of spiritual evolution. The church became a bridge between matter and the spirit. The cross was transformed into a metaphor that rescues and unites the material and the spiritual. According to Renina Katz, "the cross, its basic element [...] does not occupy the center as a conventional focus; it is present throughout the movement of the panel [...] it is more important to integrate than to break the dualities and ambivalences of the human condition" [11].

Actually, the experience of the triptych of the Mãe do Salvador Church serves as an essential module for the artist's later actions in public art. The notions of seriation and repetition remain in the implantation of the panel, particularly in what refers to the application of abstract expression - the same as printmaking. The artist uses an arrangement of residues obtained from carving the surface of the wood with a chisel or straight carving tool. This concept was also applied in other experiments, giving rise to the engraving of enlarged bands that are nothing more than the grooves made on printing matrices. Maria Bonomi introduces the parallel planes and materials for the enrichment of the image, constituting metaphors that integrate the (profane/sacred; man/spirit) ambivalences.

However, the enlarged groove, the cutting and the residual coupling of reliefs are transformed into a basic alphabet of this language. The simple and indirect abstract language takes on the role of integrating the architectural space. The work also receives a theatrical lighting, inherited from the scenographic work the artist began doing in 1960. Bonomi intensified her research in relation to the materials and, specifically, improved her procedure with the workers. This is because the work is entirely executed with materials available in civil construction having concrete as a basis - and carried out using actual construction workers.

The two façades of the Esporte Clube Sírio, realized in 1977, presented the artist with the challenge of integrating them to the visual landscape. Unlike the triptych of the Mãe do Salvador Church, it was necessary to consider the exterior aspect of the work. The façades are located in an environment dominated by the street. The realization of the panels required the application of materials able to function effectively in the urban space, conveying to the passers-by the idea of dynamism and sports activity. For this, Bonomi used low relief on slabs, on which a design is modeled according to how the sunlight falls on it, forming a constant interplay between light and shadow. The perspective of a link between art, knowledge and memory is present in the façades, furnishing the measure of integration with the urban space, in which they are inserted. The artist admits: "Behind the 'appearance' of the east and west façade of the Sírio there is a small history [...] it is always the history of man, his decisions and achievements, the sum of his efforts and the anonymous nature of his hopes for peace and leisure [...]" [12].

In the construction of the panels of the lobby of the Maksoud Plaza Hotel, Maria Bonomi evinced her concern in regard to the consumption of the image as landscape. The thematic relation with memory is textual, in this conception. The question is directed to the space of art, instituting the binomial "landscape and memory." The panels, with an area of $300 \mathrm{~m}^{2}$, are inspired in the landscape of the Philippines (plantations of rice in the province of Benguet, which the artist has never seen, except by way of photographs that show the work of grooving the earth). The memory represented in the panel is present less in the landscape of Benguet than in the groove transposed from the photograph of the landscape to the concrete. There are two panels: 1) Paisagem, which precisely depicts the rice fields of Benguet, composed of four fundamental grooves in the engraving; 2) Memória, which is located on the opposite wall, facing the first, and which plays with the same forms, the same design; in short, the same panel, with the difference that the composition is established based on nonsynchronized elements. For the artist, the panels represent the conscious and the unconscious, being that the second one is exactly the memory of the experience of those grooves represented in the first panel.

In the panels, Maria Bonomi transposes the groove from the wood (the woodcut) to another technique and function. The groove abandons the representation of the cut to become a figure or situation. It is the groove that constitutes the geometric forms and attributes rhythm to the panel. However, the groove also refers to the memory of the engraver. The designs formed by the alternating grooves and by the two colors of the concrete that separate the inclined part from the straight part configure a transport of language. In the end, the mural is a tridimensional engraving that explicates the artist's reflections concerning the plasticity of space, movement, color and light - there are two concepts: that of recovery 
of the landscape and that of urban archaeology. In the panels Paisagem and Memória, Maria Bonomi develops two of the concepts essential to her work in murals: the grooving as an expression in and of itself, and not as instrument at the service of engraving; and the use of reinforced concrete, in the importance increasingly attributed to the collective space.

During the 1980s, the artist intensified her work in more differentiated techniques, such as sculpture, scenography and costume design. Late in that decade, Maria Bonomi returned to woodcut; however, the technique of carving in the wood was now applied to a new support: concrete. Simultaneous with the change in support, Maria Bonomi's works were directed increasingly to public spaces. Beyond those already mentioned, Maria executed murals on the façade of the Jorge Rizkallah Jorge building, on Av. Paulista, on the corner with Rua Bela Cintra, and similar projects in private residences.

Maria Bonomi's artistic practice, based in the technique of engraving, leads to the following reflection: the copy of the single engraving in reinforced concrete offers a singular experience in this genre. The artist, with the chisel and burin, creates the piece in concrete, surrounded by the procedures of engraving and sculpture, resulting in a macro-engraving of a monumental character and, generally, surrounded by the public space of the city. The possibilities in regard to aesthetic sensibility for this work are potentized by these two aspects.

\section{The Technique of Mural}

These realizations consolidate the technique of mural making, in concrete, within the artist's poetics. For her, the concrete is the material for the realizations in the mold. "Concrete is an exciting interlocutor of everything that is presented on the surface or inside a groove exactly like a musician executes a musical score" [13]. The use of concrete is allied to the conceptions involved in public art, that is, it fosters respect for the context and for the dialogue with the public, rather than merely conceiving the space as a "colonizable" place. Bonomi points out that the concrete and the public space can be improved; that the workers can produce site-specific products knowing precisely which segment of the public will be the users of that work.

In this context, the composition of the murals is allied to the theme, which is represented as an important factor in the dissemination of the artwork. For Maria Bonomi, the murals serve as supports for narratives of the memory linked to historical and identificatory aspects of the city of São Paulo; the murals are transformed into messages directed to the passers-by of the public space of the city.

In 1989, when the Memorial da América Latina was still under construction, Maria Bonomi was invited by Oscar Niemeyer to erect a panel made of soil cement, called Futura-Memória [Future-Memory]. In this panel, the artist inscribed mythic Latin American traditions that are extended throughout the entire territory, from Mexico to Patagonia. By way of signs, she related beliefs and convictions able to unite Latin America in a single direction, from its remote times until an unknown future. The figurative elements are combined with the abstract lines (or even with the grooves) of the engraving. This engraving is transformed into a panel, demonstrating the territory's identificatory, archaeological and geological unity. While in terms of ideals, Futura-Memória is deeply identified with the Memorial da América Latina, especially, in relation to the construction in matteric terms, it constitutes a counterpoint: the soil cement evokes the land in a space dominated by concrete. For the artist, the awakening of shared ancestral memory is concentrated, also, in the land/soil element.

The conception of the panel Construção de São Paulo [Construction of São Paulo] was begun in 1994 and brought forward in 1997 in the Jardim São Paulo Subway Station. In this panel, the daring of the public art espoused by Maria Bonomi confronts the challenge of awakening sensibility in a territory of aggressive passage: São Paulo's subway stations receive millions of people per day. How can art be inserted in this hectic everyday setting? Bonomi chose the memory of São Paulo as her weapon. In this one work, she brings together the image of the [rocky outcropping called] Pico do Jaraguá (an homage and citation to engraver Evandro Carlos Jardim), modulated reliefs of reinforced concrete and the juxtaposition of scenes of the great metropolis. The panel's construction was inserted in the subway station's construction schedule. Construction workers lived side-by-side with the artist's team. The execution of the work was carried out in strict coordination with the construction of the station itself.

For the perception of the work, in the day-to-day activity of the station, Bonomi appealed to a nocturnal, internal and introspective view of the panel, while not ignoring the sound provoked by the constant movement of the crowds [14]. Another important detail: the public would always view the work while in movement whether seeing it from the train or the platform, the spectator will always be moving and see the work from fragmented angles. The spectator must then reconstitute the totality of the cubes to form an image of the city of São Paulo, as two worlds: the outside one and the underground one.

In the panels Imigração and Substituição, present in the Palácio Bandeirantes, Maria Bonomi used materials such as aluminum and brass, fastened in a framework of drawn iron, using carving instruments to manually engrave the clay. Following this, the plaster mold is submitted to the lost-wax process and the material is cast in aluminum by the green sand system, with polishing and patina. By way of graphic resources, in dramatic and expressionist carvings, these panels tell of the sensibility and history of the human masses in their migrations and displacements. They narrate physical and spiritual elements. "They show the saga of those who arrived and settled, those who plow the land - similar to the artist who works in her clay [15]. They tell about the nomads who became sedentary. A history of struggles, sufferings and redemption. The marks of those who passed by here. Vestiges from the 19th and 20th centuries. In the background, a reminiscence of São Paulo's recent history resignified for the place where the panels are installed - the headquarters of the São Paulo State Government.

In 1998, invited by the Bienal Barro de América Roberto Guevara, in Maracaíbo, Venezuela, Maria Bonomi conceived an installation in which she disassembles the idea of the ephemeral that accompanies 
any work of this nature. Installation was a new field for the engraver, who had previously worked with panels and sculptures. In Sobre a Essência: Os Sete Horizontes do Homem [Concerning the Essence: The Seven Horizons of Man], the artist created a universe in which the successive layers of mirror, salt, glass, coal, clay, cement and soil can be set up anew at any site. By way of a set of instructions, the artist orients the process for manufacturing the installation, indicating the paths to be followed and the materials to be used.

The installation is made up of layers of sand, salt, broken glass, coal, expanded clay, cement and soil. Below all of the layers, on the floor, there is a flat mirror, which lies on a plastic film covered by unconnected texts by anonymous authors. The inscription invades the installation, forming a discursive proliferation. The presence of writing establishes interactions between the work Sete Horizontes and the public art proposed by Maria Bonomi. In the artist's view, the multiplicity of discourses has greater chances of reaching the diverse spectators. The installation also bears relations with the panel Futura-Memória, located at the Memorial da América Latina, since it evokes ancestral discourses of a univocal America, by way of the soil/land and other primordial elements. It also involves references to engraving, insofar as it explores grooves and layers.

\section{Final Thoughts}

Maria Bonomi's itinerary shows that it is certainly possible to work on a single language throughout one's entire life. However, this language, in each phase of its production, will never be the same. At each intervention, even though the support or the techniques are the same, there is a new work. Maria Bonomi reveals: "I always do the same thing, and it is always different" [16]. The essentialness of the matrix, the system of copies and the process of reproduction do not seem to matter to the engraver. On the contrary, the artist admits the possibility of a range of techniques of reproduction: the accessibility of "engraving" an idea by way of digital computers, photography, concrete, and many new techniques. What becomes essential for Maria Bonomi is her graphic approach as the differentiating aspect of each new artwork. It is the graphic approach that is in charge of bearing the message of her art.

In short, in Maria Bonomi's poetics, it is possible to detect three basic axes: the lived memory; the technique of engraving (in this context, the graphic approach, configured in the groove); and the work's public character. In these axes, the forms are repeated and multiplied in different systems of representation, acquiring a new personality each time: the artist possesses permanent themes which are constantly renewed. The main themes, regardless of the treatment and appearance, are: "Work," "São Paulo" and "Memory." Besides the above-mentioned works in this path of the "poetics of memory," Maria Bonomi has created others, such as Epopéia Paulista [São Paulo Epopee] (2004), Infecção da Memória [Infection of Memory] (2005), Frottages Verticais [Vertical Frottages] (2005), and Etnias - Do Primeiro e Sempre Brasil [Ethnicities - From the First and Always Brazil] (2006). These works establish dialogues and integrate the set of themes privileged in Bonomi's poetics. These works will be discussed, later, in the context of research, since together they configure a new procedure in Bonomi's artistic practice.

\section{References}

[1] BONOMI, M. Maria Bonomi - Identidade das Musas. (With text by Renina Katz, 1996). São Paulo, n/d.

[2] HERKENHOFF, P. Maria Bonomi - Balada do Terror. (With statement by Maria Bonomi given to Oswaldo Mendes, Jornal Última Hora, 1971, and text by Paulo Herkenhoff, "The art of Contemporary Brazil," Washington, DC, 1993). São Paulo, n/d.

[3] ESPAÇO CULTURAL BM\&F. Infecção da Memória: Maria Bonomi na BM\&F. (with text by João J. Spinelli). São Paulo, Espaço Cultural BM\&F, from 24 May to 22 July 2005, p. 6.

[4] ESPAÇO CULTURAL BM\&F. Infecção da Memória: Maria Bonomi na BM\&F. (with text by João J. Spinelli). São Paulo, Espaço Cultural BM\&F, from 24 May to 22 July 2005, Idem, p.7.

[5] BONOMI, M. Metáforas Urbanas. In: AJZENBERG, Elza. Arteconhecimento. São Paulo: MAC USP/PGEHA, 2004, p. 114.

[6] BONOMI, M. Metáforas Urbanas. In: AJZENBERG, Elza. Arteconhecimento. São Paulo: MAC USP/PGEHA, 2004, p. 114..

[7] BRESON, Michael. Perspectiva da Arte Pública. In: MIRANDA, Danilo (org.). Arte Pública. São Paulo: SESC, 1998, p. 17.

[8] "Maria Bonomi e as Pesquisas de Espaço Coletivo - Um Pulo de Saltimbanco sem a Segurança da Rede.” O Globo. Rio de Janeiro, 7 February 1980.

[9] VLAVIANOS, N. Um espaçovivo para a arte na construção de um prédio. Diário Popular. São Paulo, 29 de jul. 1973.

[10] BONOMI, M. Metáforas Urbanas. In: AJZENBERG, Elza. Arteconhecimento. São Paulo: MAC USP/PGEHA, 2004, p. 112.

[11] KATZ, Renina. "Para Sentir e Compreender o Tríptico da Igreja Mãe do Salvador.” In: BONOMI, Maria. Maria Bonomi - Cruz torta - Igreja Mãe do Salvador. São Paulo, n/d.

[12] LAUDANNA, Mayra. Maria Bonomi: da Gravura à Arte Pública. São Paulo: Imprensa Oficial/EDUSP, 2008, p. 183

[13] BONOMI, M. Metáforas Urbanas. In: AJZENBERG, Elza. Arteconhecimento. São Paulo: MAC USP/PGEHA, 2004, p. 116.

[14] BONOMI, M. Metáforas Urbanas. In: AJZENBERG, Elza. Arteconhecimento. São Paulo: MAC USP/PGEHA, 2004, p. 116.

[15] KLINTOWITZ, Jacob. Maria Bonomi, Gravadora. São Paulo: Cultura Editores Associados, 2000, p. 26.

[16] BONOMI, M. Metáforas Urbanas. In: AJZENBERG, Elza. Arteconhecimento. São Paulo: MAC USP/PGEHA, 2004, p. 112. 